\title{
Evaluation of the nutritional potentials of physically treated cowpea seed hulls in poultry feed
}

\author{
O. A. Adebiyi ${ }^{1 *}$, A. D. Ologhobo ${ }^{1}$, O. A. Adu ${ }^{2}$ and T. O. Olasehinde ${ }^{3}$ \\ ${ }^{1}$ Laboratory of Animal Nutrition and Feed Toxicology, Department of Animal Science, \\ University of Ibadan, Ibadan, Nigeria; ${ }^{2}$ Department of Animal Production and Health, \\ Federal University of Technology, Akure, Nigeria; ${ }^{3}$ Institute of Agricultural Research and \\ Training, Obafemi Awolowo University, Moor Plantation, P. M. B 5029, Ibadan, Nigeria
}

\begin{abstract}
Feeding has been reported to be responsible for the high cost observed in poultry production. The use of unconventional feedstuff for poultry production is however limited due to their fibrousness and inability of birds to possess the cellulase enzyme that can digest the fibre, nevertheless, physical treatments of these unconventional feedstuffs enhance their possibility in poultry production. The objective of this study therefore, was to evaluate the nutrient status of cowpea seed hull after being subjected to different treatment. The Cowpea seed hull that was not subjected to any form of treatment served as the control i.e. Untreated cowpea seed hull (UCH), while a portion was soaked and boiled (soaked and boiled cowpea seed hull, SBCH) and another portion soaked for 3 days, soaked cowpea seed hull (SCH). The seed hull in each treatment were analysed for their proximate composition, metabolisable energy (ME) and fibre fraction. The trial revealed a steady increase in crude protein (CP) of the test materials with the highest increase $(18.43 \%)$ in crude protein recorded in $\mathrm{SCH}$ substrate compared to $6.73 \%$ increase in $\mathrm{SBCH}$ substrate. A corresponding decrease in crude fibre (CF) was recorded with $15.00 \%$ loss for SCH substrate while $6.97 \%$ loss in crude fibre was observed for $\mathrm{SBCH}$ substrate. Changes of $1.73 \%$ and $4.22 \%$ were recorded for nitrogen free extract (NFE) in SBCH and SCH respectively, while ME changes by $1.67 \%$ and $5.39 \%$ for $\mathrm{SBCH}$ and $\mathrm{SCH}$ substrates respectively. The effects of both physical treatments on ash and insoluble ash were not significant. Fibre analysis revealed that $7.55 \%$ (53.00\% to $49.00 \%)$ and $18.87 \%$ (53.00\% to $43.00 \%$ ) of acid detergent fibre (ADF), $7.41 \%$ $(81.00 \%$ to $75.00 \%)$ and $16.05 \%(81.00 \%$ to $68.00 \%)$ of neutral detergent fibre (NDF) and $2.5 \%$ $(40.00 \%$ to $39.00 \%)$ and $22.5 \%(40.00 \%$ to $31.00 \%)$ of cellulose were loss in SBCH and SCH substrates respectively. There were no significant effects on the acid detergent lignin (ADL) and hemicellulose components of the test samples due to these physical treatments. The result revealed that the different processing methods resulted in increase in the crude protein contents with a corresponding reduction in crude fibre of the seed hull. The changes observed must have been due to fermentation that occurred during the soaking of the seedhull.
\end{abstract}

Keywords: Cowpea seed hull, fibre fractions, proximate composition.

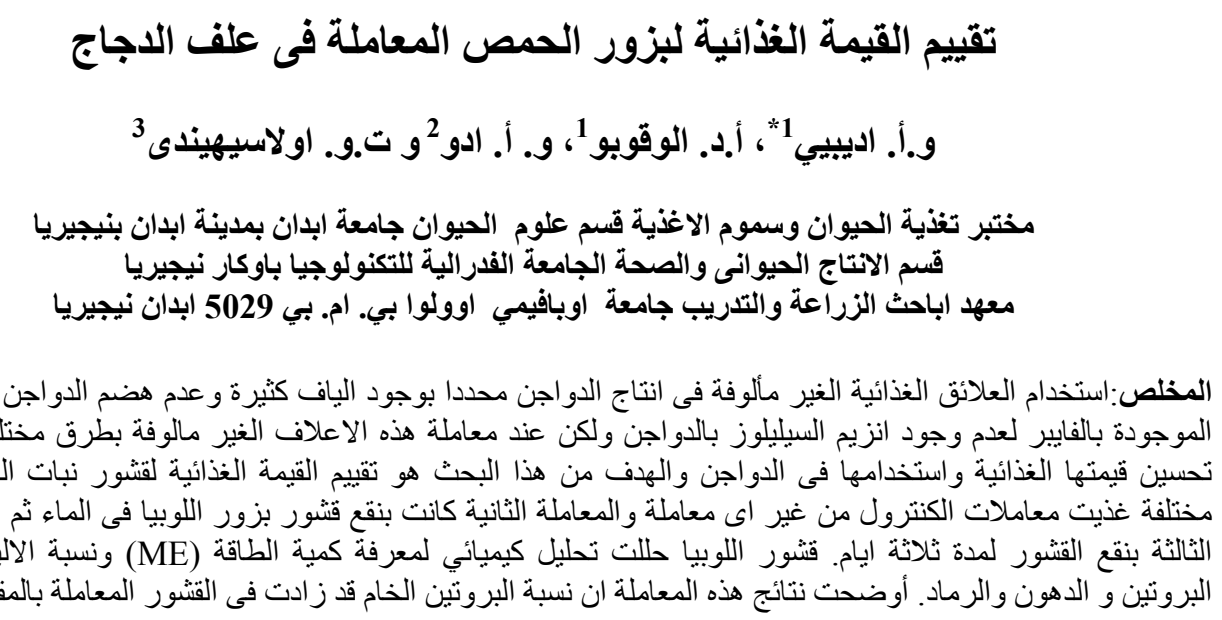

* Corresponding Author, Email: femibiyi01@yahoo.com 


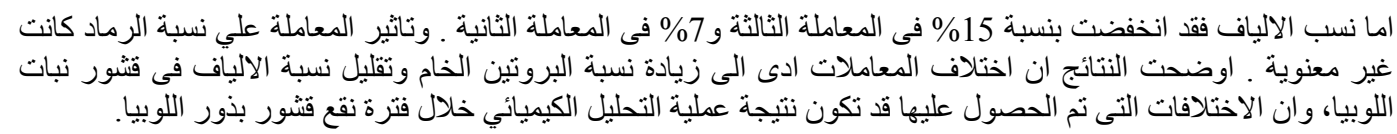

\section{Introduction}

The livestock industry in Nigeria is dependent on conventional and non conventional feed stuffs, and many researchers have opined that feed account for about $60-70 \%$ of the cost of production in livestock industry (Akinfala and Tewe, 2001). This was attributed to the high cost of feedstuffs, which are also consumed by human being and served as raw materials for agro-processing industries. In order to sustain the livestock industry and solve the problem of protein deficit as reported by Tewe (1997), agro by-products should be properly exploited, due to their availability and cost effectiveness.

Suggested possibilities to increase intake of low quality crop residue are physical treatments (chopping, grinding, pelleting). Chemical treatment (with $\mathrm{NaOH}$, urea, ammonia, sodium carbonate) and biological treatment (Singh and Schiere, 1995, Williams et al., 1997). However, since substrates are released gradually during passage through the digestive tract, treatments which increase the speed of dissolution should enhance enzyme activity by providing for a longer period of enzyme substrate interaction. Aletor and Ojo (2006), reported that cooking and autoclaving removed the anti nutritional factors in lima bean whereas Agunbiade (1992) concluded that cooking reduce trypsin inhibitor. However, Longe (1988), on meeting the energy needs for monogastric from nonconventional feed resources equally asserted the need for more research into full exploitation of potentialities of alternative ingredients. Therefore, processing technique which are simple, inexpensive and do not increase cost but still make it worthwhile in terms of nutrient availability should be pursed. Various works on pretreatment mechanism ranging from delignification, saccharrification, irradiation with high electron, subdivision into micro size particles and steeping in alkali which provide enhance utilization of food carbohydrate by bacterial enzymes have been reviewed (Benvink and Mulder, 1989).

A by-product of interest in terms of substituting conventional feed ingredient in monogastric diet is cowpea seed hull. Cowpea seed hull is a crop residue, which is available in Nigeria in large quantities. It is a post threshing residue which though high in fibre, is finding use its in ruminant nutrition. As is the case with other crop residues and agro-industrial by-products, cowpea hulls are characterized by low energy and protein, low digestibility/bioavailability and low acceptability (Faniyi, 1998).

Upgrading of these residues, improves their nutritive value, (digestibility), sterilizes, detoxifies, concentrates and by biological means produces a utilizable commodity from a substance of little initial feeding value (Wiseman and Cole, 1986).

In a bid to harness more unconventional feedstuffs to resolve the shortage of livestock feeds and products and environmental pollution, this experiment was designed to assess the nutritional potentials locked up in this crop residue and to ascertain if simple physical treatments will boost these potentials.

\section{Materials and Methods}

The cowpea seed hulls used in this experiment was obtained from the Bodija Foodstuff Market, Ibadan. Nigeria. Three experimental treatments were created; Treatment 1 was the control, untreated cowpea seed hulls (UCH). In Treatment 2, the seed hulls were soaked for 2 days and boiled for 30 minutes $(\mathrm{SBCH})$, while in Treatment 3 , the seed hulls were only soaked for 3 days ( $\mathrm{SCH})$. Each treatment is replicated five times. Post treatment, the substrates were sun dried to constant 
weight, milled and stored in ventilated bags awaiting chemical analysis.

\section{Chemical Analysis}

The samples were analyzed for proximate component (dry matter, crude protein, crude fibre, ether extract and ash) using methods Association of Official Analytical Chemists (AOAC, 1990). While the NFE was estimated by the difference of the summation of the crude protein value, crude fibre, ether extract and ash from 100. The crude fibre fractions were analysed using the procedure of Van Soest and Mason, (1991). The ME was calculated using the equation of Pauzenga (1985) as follows:

Metabolisable Energy $(\mathrm{kcal} / \mathrm{kgDM})=37 \mathrm{x}$ $\%$ protein $+81.8 \times \%$ fat $+35.5 \times \%$ NFE

Gross Energy was calculated based on the procedure of Ekanayake et al. (1999) as follows:

Gross Energy $(\mathrm{kj} / 100 \mathrm{gDM})=(\%$ protein $\mathrm{x}$ $16.7)+(\%$ lipid $x \quad 37.7)+(\%$ carbohydrates x 16.7)

Percentage Carbohydrates was estimated based on Miller and Tobin (1980).

Total crude carbohydrate $(\%)=100-$ (crude protein + crude lipid + crude fibre + ash)

\section{Statistical Analysis}

Data were subjected to statistical analysis of variance (ANOVA) of SAS
(1999) to determine the co-efficient of variation.

\section{Results and Discussion}

The results of the proximate analysis and crude fibre assay of the tests ingredients are presented in Table 1 and Figure 1 respectively. Crude protein was $14.11,15.07$ and $16.71 \%$ for $\mathrm{UCH}, \mathrm{SBCH}$ and $\mathrm{SCH}$ respectively. Table 1 shows an increase in crude protein of the test ingredient with highest change of $\mathrm{CP}$ recorded in $\mathrm{SCH}$ substrate (18.43\%) compared to $6.73 \%$ change in $\mathrm{SBCH}$ substrate. A corresponding loss of $6.97 \%$ $(30.00 \%$ to $28.21 \%)$ in $\mathrm{CF}$ content of $\mathrm{SBCH}$ substrate and $15.00 \%(30.00 \%$ to $25.50 \%$ ) loss in $\mathrm{CF}$ content of $\mathrm{SCH}$ substrate were observed. The result also showed the dry matter content of the seed hulls which range from $89.30 \%$ in $\mathrm{SBCH}$ to $90.00 \%$ in $\mathrm{SCH}$, while ash and insoluble ash contents for the different treatments were not widely apart. The values observed for ether extract varied are $9.30 \%, 9.54 \%$ and $9.66 \%$ for $\mathrm{SBCH}, \mathrm{SCH}$ and $\mathrm{UCH}$ respectively. The $\mathrm{ME}$ was greatly affected by the treatment to which the seed hulls were subjected. The ME increased from $2642.80 \mathrm{kcal} / \mathrm{kg} \mathrm{DM}$ in $\mathrm{UCH}$ substrate to $2785.29 \mathrm{kcal} / \mathrm{kg} \mathrm{DM}$ for $\mathrm{SCH}$.

\section{Table 1. Proximate analysis of Cowpea seed hulls subjected to different physical} treatments.

\begin{tabular}{llll}
\hline Parameters & $\mathbf{U C H} \pm \mathbf{S D}$ & $\mathbf{S B C H} \pm \mathbf{S D}$ & $\mathbf{S C H} \pm \mathbf{S D}$ \\
\hline Dry Matter (\%) & $89.34 \pm 3.42$ & $89.30 \pm 2.87$ & $90.00 \pm 4.21$ \\
Crude Protein (\%) & $14.11 \pm 0.32$ & $15.06 \pm 0.52$ & $16.71 \pm 0.45$ \\
Ether Extract (\%) & $9.66 \pm 0.35$ & $9.30 \pm 1.02$ & $9.54 \pm 1.24$ \\
ASH (\%) & $8.75 \pm 0.27$ & $9.30 \pm 0.48$ & $9.19 \pm 0.23$ \\
Crude Fibre (\%) & $30.00 \pm 2.43$ & $28.21 \pm 2.67$ & $25.50 \pm 1.98$ \\
Insoluble Ash (\%) & $1.30 \pm 0.07$ & $1.00 \pm 0.06$ & $1.40 \pm 0.09$ \\
Metabolisable Energy (kcal/kg) & $2642.80 \pm 8.98$ & $2698.56 \pm 8.54$ & $2785.29 \pm 10.21$ \\
Gross Energy (kcal/kg) & $2930.98 \pm 9.56$ & $3097.21 \pm 8.89$ & $3227.54 \pm 7.91$ \\
Nitrogen Free Extract (\%) & $37.48 \pm 3.31$ & $38.13 \pm 2.21$ & $39.06 \pm 2.31$ \\
\hline
\end{tabular}

SD: Standard deviation; UCH: untreated cowpea seed hulls; SBCH: seed hulls soaked for 2 days and boiled for 30 minutes; SCH: seed hulls only soaked for 3 days. 


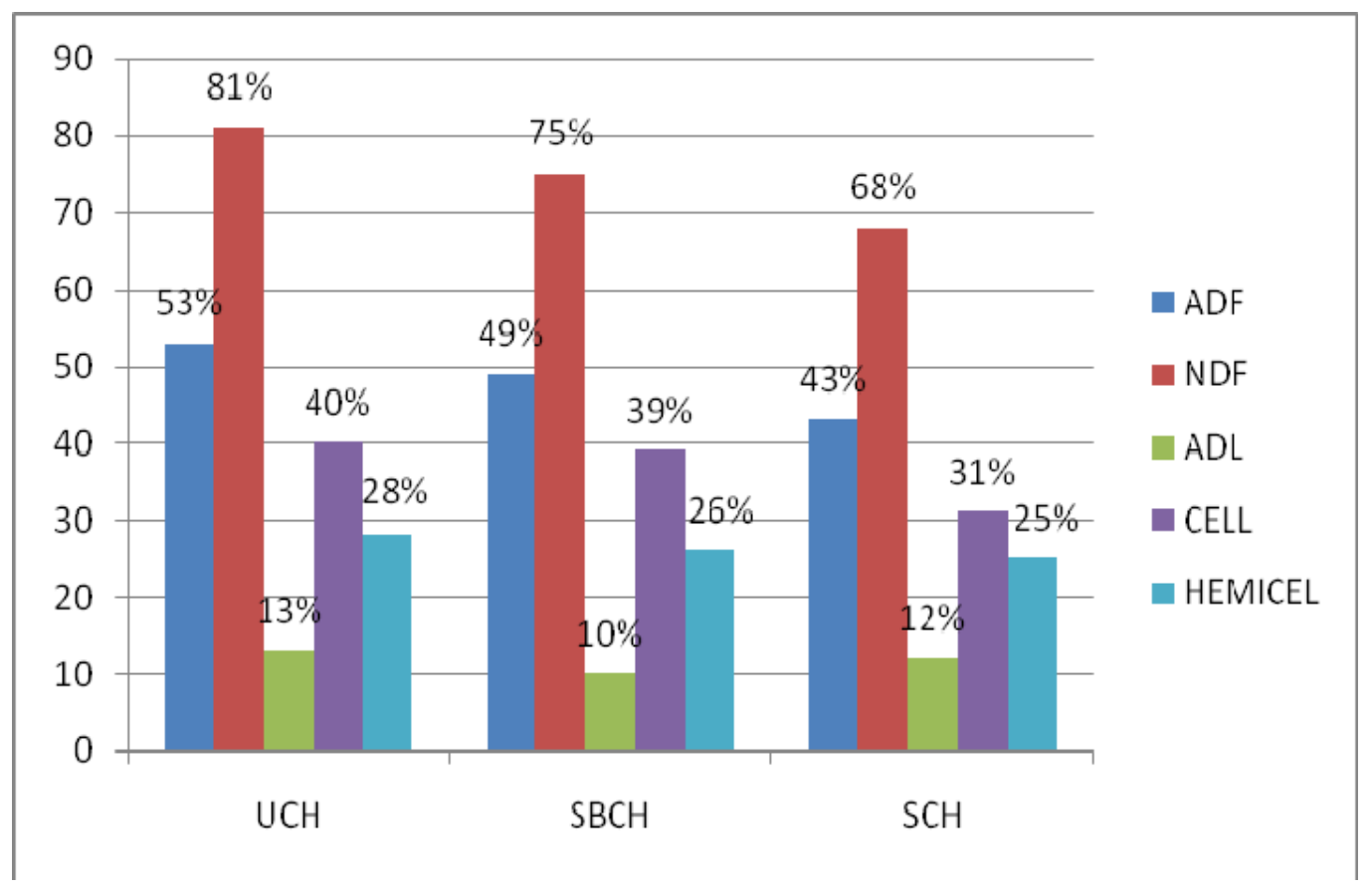

Figure 1. Lignocellulosic fractions of cowpea seed hulls subjected to different physical treatments.

The result revealed that $7.55 \%$ $(53.00 \%$ to $49.00 \%)$ and $18.87 \%(53.00 \%$ to $43.00 \%)$ of $\mathrm{ADF}, 7.41 \%(81.00 \%$ to $75.00 \%)$ and $16.05 \%(81.00 \%$ to $68.00 \%)$ of NDF were broken down in SBCH and $\mathrm{SCH}$ respectively. However, the cellulose content of UCH decreased from $40.00 \%$ to $31.00 \%$ in SCH (Figure 1). The least reduction in $\mathrm{ADL}$ was observed in $\mathrm{SBCH}$ substrate $(10.00 \%)$, while $13.00 \%$ and $12.00 \%$ were recorded for $\mathrm{UCH}$ and $\mathrm{SCH}$ respectively.

The result revealed that the different processing methods caused an increase in the CP contents of the products. The changes observed must have been due to fermentation that occurred during the soaking of the seed hull. Fermentation of food described by Campel-Platt (1994) as animal or plant tissue subjected to the action of micro-organisms which gives a desirable biochemical changes and significant modification of food quality. One of the several functions of fermentation according to Steinkraus
(1995) is the enrichment of diet and the removal of toxin.

During soaking, the endogenous enzymes in the seed hulls were activated (Singh and Shukla, 1993) breaking the polysaccharide during proliferation into their respective oligomers. The increase in $\mathrm{CP}$ values is due to the effect of heating on lignocellulosic materials which generate undegradable Maillard products (Van Soest and Mason, 1991), which are detected by an increase in the nitrogen content of the cell wall. As the protein is increasing in the fermented substrates ( $\mathrm{SCH}$ and $\mathrm{SBCH})$, the crude fibre is decreasing. This is because during microorganism proliferation, polysaccharides are broken down to monosaccharides thus, reducing the crude fibre causing an increase the $\mathrm{CP}$ and $\mathrm{ME}$ contents as observed in this study.

Boiling however, has been implicated in gelatinisation (the irreversible loss of the crystalline regions in starch granules that occurs upon heating in the presence of water) of starch. Gelatinization 
dramatically increases the availability of starch for digestion by amylolytic enzymes. But since gelatinized starch is not in thermodynamic equilibrium, therefore, a progressive re-association of starch molecule-retrogradation-occurs which may reduce the digestibility of the starch (Reid and Hillman, 1999). Resistant starches according to Acamovic (2001) are less easily degraded by enzymes because of the differences in their chemical structure, as well as their physical nature. The reduction in crude protein content of $\mathrm{SBCH}$ substrate compared to that of $\mathrm{SCH}$ substrate could be due the loss of protein and essential amino acid during boiling as explained by Umoh and Bassir (1980) and resistant starch formed as a result of the heating process. These provide ground for the better performance of $\mathrm{SCH}$ over $\mathrm{SBCH}$.

Nitrogen free extract (NFE) was also observed to follow the same trend as $\mathrm{CP}$ and $\mathrm{ME}$ with $\mathrm{SCH}$ being significantly different from UCH. This is as a result of the treatment effect on the seedhull.

\section{Detergent fibre analysis of untreated and physically treated cowpea seed hulls}

Chemical composition and physical structure are responsible for the underutilization of lignocellulose complexes (Vander voorde et al., 1988) of which cowpea seed hulls belong to this group. Thus, the variations in the detergent fibre fractions of the cowpea seed hulls could be explained from their chemical composition and processing techniques used. Fermentation broke down the fibrous structures of the cowpea seed hulls cellulose, cellobiose and $\beta$ glucose.

Willis et al. (1980) reported that some physical or chemical modification may be beneficial for improved utilization of residues with high lignin and cellulose contents. Thus, the grinding and partial digestion may improve utilization of the hulls by poultry.
Though, cellulose play a structural role in plant cell wall, its crystalline nature is an obstacle to its direct utilization in animal nutrition (Vander-voorde et al. 1988). Reduction of cellulose of the SCH and SBCH (Figure 1) compared to the $\mathrm{UCH}$ suggests that the fibre in these seed hulls may have been digested. In fact McDonald et al. (2002) reported that cellulose is broken down to cellobiose which is digested further to yield $\beta$ glucose.

Hemicellulose is heterogeneous polymer closely associated with cellulose and composed of xylose, mannose, glucose, galactose and arabinose. It consists of about $10-25 \%$ DM of legumes and hulls (de Vries and Visser, 2001). Hemicellulose was high in the UCH but low in $\mathrm{SCH}$ and $\mathrm{SBCH}$ probably due to loss in the water. Castro et al. (1993) also showed that steam treatment has been reported to lead to partial hemicellulose hydrolysis, lignin depolymerisation and cell wall swelling.

The result showed slight changes in the lignin contents of the three treatments, although the values in the $\mathrm{SCH}$ and $\mathrm{SBCH}$ are lower to $\mathrm{UCH}$, this could be as a result of the milling process that the three samples were subjected to, thus increasing the surface areas and further treatments brought about the reductions observed in $\mathrm{SCH}$ and SBCH. Gordon et al. (1983) reported that lignin is not only a bind component of the hemicellulose matrix, it also form part of the lignin carbohydrate complex stabilized by phenolic acid (Ferulic, 4-Coumaric acid) and acetyl constituent of the cell wall.

\section{Conclusion and Recomendation}

From the result obtained in this study, it can be concluded that both $\mathrm{SCH}$ and $\mathrm{SBCH}$ are possible physical methods for upgrading the quality of cowpea seed hulls for use in livestock nutrition. 


\section{References}

Acamovic, T. 2001. Commercial application of enzymes technology for poultry production. World Poultry Sci. J. 57:225-236.

Agunbiade, S. O. 1992. The physical, chemical and nutritional characteristics of the African Yam bean, Sphenostyles stenocarpa. Ph.D. dissertation, University of Ibadan, Ibadan, Nigeria.

Akinfala, E. O. and O. O. Tewe. 2001. Utilization of whole cassava plant in the diets of growing pigs in the tropics. Livestock Research for Rural Development.

Aletor, V. A. and O. I. Ojo. 2006. Changes in differently processed soya bean (Glycine $\max$ ) and lima bean (Phaseolus lunatus) with particular reference to their chemical composition and their mineral and some inherent anti-nutritional constituents. Mol. Nutr. Food Res. 33(10):1009-1016.

Association of Official Analytical Chemist. AOAC. 1990. Official Method of Analysis (12 $2^{\text {th }}$ edition) Washington D.C. USA.

Benvink, J. M. N and M. M. Mulder. 1989. The plant cell wall; architecture of the plant cell wall fragments, cell wall degrading enzymes and their possible use in ruminants and monogastric livestock feeding. Nutr. Res. 200:141.

Castro, F. B., P. M. Hotten, and E. R. Skov. 1993. The potential of dilute acid hydrolysis as a treatment for improving the Nutritional quality of industrial lignocellulosic byproducts. Anim. Feed Sci. Technol. 42:39-53.
Campbell-Platt, G. 1994. Fermented foods of the World. A. Dictionary and guide, Butterworths, London.

de Vries, R. P., and J. Visser 2001. Aspergillus Enzymes Involved in Degradation of Plant Cell Wall Polysaccharides. Microbiol. Mol. Biol. Rev. Appl. Microbiol. Biotechnol. 38:688-695.

Ekanayeke, S., E. R. Jansz, and B. M. Nair. 1999. Proximate composition, mineral and amino acid content of mature Canavalia gladiata seeds. Food Chem. 66:115-119.

Faniyi, G. F. 1998. Biochemical Characterization and Utilization of Cowpea (Vigna unguiculata) and Sorghum (Sorghum bicolor) Seed hulls upgraded with non- proteinous nitrogen in broiler rations. $\mathrm{Ph}$. $\mathrm{D}$. dissertation, University of Ibadan, Ibadan, Nigeria.

Gordon, H. H., J. A. Lomax, and A. Chesson. 1983. Glycolytic linkages of legume, grass and cereal straw walls before and after extensive digestion by rumen micro-organisms. J. Sci. Food and Agric. 34:1341-1350.

Longe, O. G. 1988. Meeting the energy need of non-ruminants from nonconventional feed resources in Nigeria. Paper presented at Rural Management Training Institute (ARMTI) Ilorin, Nigeria. November 21-28.

McDonald, P., R. A. Edwards., J. F. D, Greenhalg and C. D. Morgan. 2002. Animal Nutrition. $6^{\text {th }}$ ed, Pearson Education Harlow.

Miller, H. G. and G. Tobin. 1980. Nutrition and food processing. Croom Helm Ltd. London. p. 302. 
Pauzenga. 1985. Feeding Parent Stock, Zoo Technica International. pp. 2223.

Reid, C. A. and K. Hillman. 1999. The effects of retrogadation and amylase/amylopectin ratio of starches and carbohydrate fermentation and microbial populations in the porcine colon. Anim. Sci. 68:503-510.

SAS Institute. 1999. SAS User's Guide Statistic, Version $6,4^{\text {th }}$ Edition, SAS Institute Inc. Cary NC.

Singh, P. K. and A. N. Shukla. 1993. Survey of mycoflora counts, aflatoxin production and induced biochemical changes in walnut kernels. J. Stored Prod. Res. 44(2):169-172.

Singh, K. and J. B. Schiere. 1995. Principle and Application with Emphasis on Indian Livestock Production. Handbook for straw Feeding System. TCAR/WAU. New Delhi India. pp. 428.

Steinkraus, K. H. 1995. Production of Vit $\mathrm{B}_{12}$ in tempeh. Proc. Asian Symposium on Non- salted soybean fermentation Tsukuba Science city; National Food Research Institute. Tsukuba, Japan. pp. 205-208.

Tewe, O. O. 1997. Sustainability and development paradigms from Nigeria livestock industry. An inaugural lecture delivered at the University of Ibadan, Ibadan. pp. 1-42.
Umoh, I. B. and B. Bassir. 1980. Nutrient changes in some Nigerian traditional peasant food during cooking III. Essential amino acid composition. Nig. J. Nutri. Sci. 1(1):48-53.

Van Soest, P. J. and V. C. Mason. 1991. The influence of Maillard Reaction upon the nutritive value of fibrous feed. Anim. Feed Sci. Technol. 32:4553.

Vander-voorde, L., B. Bruyneei, and W. Verstraete. 1988. In-reactor cellulose conversion. Anim. Feed Sci Technol. 21:99-125.

William, O. T., S. Fernandez and T. G. Kelley. 1997. The influence of socioeconomic factors on the availability and utilisation of crop residues as animal feeds. In: C. Renard (Ed). Crop Residues in sustainable mixed crop- livestock farmining system. Proceedings of the International Workshop ICRISAT. ILRI CAB International, Addis Ababa, Ethiopia. pp. 25-39.

Willis, C. M., O. T. Stallcup, and D. L. Kreider. 1980. Influence of Sodium hydroxide and enzymes addition on nutritive values of rice straw. J. Anim. Sci. 50(2):303-310.

Wiseman, J. and D. J. A. Cole, 1986. The Utilization of Waste in Animal Feeds. In: D.A Leward, A.J, Taylor and R.A Lawrie (Eds). pp.234-236. Upgrading Waste for Feeds and Food by Butterworths, London 